\title{
The Problem of the Potsherd: Job 2:8 in a New Perspective
}

\author{
ELLEN VAN WOLDE (RADBOUD UNIVERSITY, NETHERLANDS)
}

\begin{abstract}
The famous verse in the prologue of the book of Job, which is commonly translated with "Job took a potsherd to scrape himself while he was sitting among the ashes," is the object of study here. In this analysis of Job 2:8, three components are extensively discussed; (1) The syntactic structure that shows that the subject of the action of "taking" is the satan and not Job; (2) The semantic analysis of the occurrences of the noun חרש, which demonstrates that this word does not designate "potsherd," but "pot"; and (3) The semantic analysis of the infinitive hitpael התגרד, which explains the satan's goal in bringing Job a pot, namely to squeeze out his inflamed boils that cover him from head to toe.
\end{abstract}

KEYWORDS: Book of Job, translation, interpretation

\section{A INTRODUCTION}

"The devil is in the details" is a well-known adage in biblical studies. Without paying attention to details in language use, text, and culture, many elements of meaning in the Hebrew Bible would have escaped our attention. The present article considers one such small detail and with some remarkable consequences. ${ }^{1}$ It regards the famous verse in the prologue of the book of Job, viz. 2:8, commonly understood to represent Job's behaviour, as is apparent in the following translations: "Job took a potsherd to scrape himself while he was sitting among the ashes" (NAS translation); "Job took a potsherd with which to scrape himself, and sat among the ashes" (NRS); "He took a potsherd to scratch himself as he sat in ashes" (NJPS). Each of the components of this verse will be analysed: the question who is the subject of the verb "taking," the noun that is commonly understood to designate "potsherd," and the verb "to scratch." This also explains the structure of the present article: after a general description of the contents of the prologue of Job and an explanation of its narratological and

* Submitted: 04/10/2018; peer-reviewed: 05/11/2018; accepted: 14/12/2018. Ellen van Wolde, "The Problem of the Potsherd: Job 2:8 in a New Perspective," Old Testament Essays 31 no. 3 (2018): 692-704. DOI: https://doi.org/10.17159/23123621/2018/v31n3a16.

1 The present study is made in honour of the eminent Old Testament scholar Prof Wilhelm Wessels. His studies of prophetic texts in close connection to themes of leadership and ethics have significantly enriched the field. 
syntactic structure, I will subsequently zoom in on the syntactic structure and the semantic content of Job 2:8.

\section{B GENERAL CONTENT OF THE PROLOGUE OF JOB}

A story of devastating misfortune is told in the prologue of the book of Job and goes through various phases. From a legendary honest, wealthy, and God-fearing man, Job's fortune suddenly changes. Within the blink of an eye this god-fearing man who had everything has lost everything.

Surprisingly, chapters 1 and 2 offer an explanation of why this happened. It seems that Job's misfortune, or the shift from fortune to misfortune, was the consequence of a deal made in heaven. Through the description of a meeting by the divine council we find out what lies behind Job's misfortune from heaven's perspective. In this meeting, Yhwh opens the discussion (in Job 1:8) by asking a fellow divine being, one of the sons of God called the satan, the following question: "Have you noticed my servant Job? There is no one like him on earth, a blameless and upright man who fears God and shuns evil!" The satan replies (in Job 1:9), "Is it 'for naught' (חנם) that Job has put his faith in you? You have protected him, all his life." In this sense, the satan argues that the principle of retribution, or 'tit for tat,' drives human behaviour, including Job's model behaviour. In other words, the satan claims that Job puts his faith in God only because God protects him and makes sure things go well for him. God takes the opposite position. Simply put, God assumes that Job is pious at the same time as being rich, whereas the satan claims that Job is pious because he is rich and wants to stay rich. Challenged by the satan, God places his bet on Job. It is an important question for God: do people fear God unconditionally or do they put their faith in him in order to ensure they stay well off? God cannot test everyone, so he puts Job, the epitome of a pious man, to the test. The aim is to answer the following questions: is humanity's loyalty to God pure, that is to say not driven by selfinterest? Are disasters the consequence of bad behaviour or caused by a lack of trust in God? Do human beings who live a good life deserve happiness? Did Job deserve happiness? Is there any rationality behind the alternation of fortune and misfortune on earth? To demonstrate the significance of these questions, the narrator sets the exchange between God and the satan in heaven. Here the discussion between God and the satan can be more open and intense. However, only the readers know about the wager. The character Job knows nothing of this heavenly experiment.

The next scene is set on earth and shows how Job reacts when blow after blow strikes. Although deeply miserable and unable to understand what is happening to him, he does not blame God. Instead he says: "Naked I came from my mother's womb, and naked I shall return. Yahweh has given and Yahweh has taken away; blessed be the name of Yahweh" (Job 1:21). The interesting point of this response is that Job does not consider misfortune as mere bad luck or as something inexplicable that happened by accident, but he attributes everything, 
either good or bad, to God. Job accepts that this is how the world works: God is sovereign and humans have to accept the way things go.

But then, new disasters strike Job. This time his body is affected and his skin peels away until his body is raw, and yet still he utters no reproach. Suddenly Job's wife turns up. Where did she come from? She was not mentioned before. ${ }^{2}$ The narrator told us about Job's sons and daughters but never mentioned a wife, and when he lost his offspring there was no reference to her either. In his deepest misery Job says that he is all alone in the world ("naked I came, naked I will go") without mention of a wife - apparently she does not count. Yet, now Mrs Job enters the picture and challenges her husband: "Do you still keep your integrity? Say good-bye to God (אלהים) and die" (Job 2:9). Embedded in her words are questions such as: "How can you keep on being loyal to God when all this misfortune befalls you? Why are you being targeted? You, my dear husband, do not deserve this. You live an upright life, I can testify to it." Job's wife is motivated by the principle of causality as the steering principle of faith: you place your trust in God since he is the one who made you, supports you, perhaps, even punishes you when you deserve it. There appears to be balance in this Godcreated universe. But disaster and misery prove that such a balance does not exist, so you might as well give up your loyalty to God. Yet, Job dismisses his wife's words as foolish: "Should we accept good from the hands of the deity, but should we not accept evil?" (Job 2:10). Still, her words have an effect. By confronting Job with his own death and pointing out to him the choice between blessing God or saying good-bye to God, she forces him to respond. His wife introduces the notion of death, and this instils doubt in Job and he begins to ask himself questions. He even starts to reason from a human point of view instead of automatically adopting the perspective of God. His wife's taunts trigger Job to change from an assured believer into someone who asks questions. The responses of an ardent believer would not have provided material for such a dramatic story. The book of Job is made human and lifelike through the doubt and spirit of a man who has to confront his trust in God in the light of the suffering, misery, and undeserved and devastating bad luck that has befallen him.

Thus the opening chapters of the book of Job explore the theme of chance through narrative. ${ }^{3}$ What seems to be an inexplicable change of fortune on earth

2 Her namelessness, her absence in chapter 1, her short and unclearly presented speech in chapter 2, and her departure after the second chapter of the book of Job never to return in the rest of the book, have aroused interpreters' interest in Job's wife throughout history. For a survey, see E.J. van Wolde, Mr and Mrs Job (London: SCM Press, 2003) and E. O. Gravett, "Biblical Responses: Past and Present Retellings of the Enigmatic Mrs Job," Biblical Interpretation 20 (2012): 97-125.

3 See E.J. van Wolde, "Chance in the Hebrew Bible: Views in Job and Genesis 1," in The Challenge of Chance. A Multidisciplinary Approach from Science and the Humanities, ed. K. Landsman and E. van Wolde (The Frontiers Collection, Springer: Open Access, 2016), 131-50. 
is described as the consequence of a wager in heaven. The bet turns out to be a kind of empirical research. God's hypothesis is that people serve him 'for naught.' His is a framework of non-causality. The counterhypothesis, formulated by the satan, is that people serve God in order to secure a better life for themselves. His framework is one of causality. The test is performed on God's model servant on earth, Job. By alternating between scenes on earth and scenes in heaven, the reader is able to view the topic from two perspectives through the characters in the two domains, i.e., God and the satan in heaven, and Job and his wife on earth. By positioning the four characters in a kind of matrix, the narrator reveals his preferences. The narrative strategy of Job 1-2 is to convince readers to share both God's and Job's point of view and agree with them that it is enough to accept that everything (good luck and bad luck) is given or taken away by God. The narrator concludes that the satan and women (not just Job's wife) hold a point of view that is seductive but incorrect. However, by introducing these opposing characters, readers are challenged to consider questions such as: Are the concepts of causality and retribution helpful in understanding the incidents of fortune and misfortune in someone's life? Are patterns of regularity, logic, and ethical balance sufficient to explain the unexpected disruptions in someone's life or not?

\section{THE NARRATOLOGICAL COMPOSITIONS OF THE PROLOGUE}

The section above resumes the content of Job 1-2, the "what" of the story. The syntactic and narratological analysis regards the "how" of the story, that is, the way in which the story is told, and deals with questions such as: How is the text syntactically organised? In what way does the narrator presents the events? How are the protagonists characterised? How are their speeches represented? Whose perspective is shared? These and similar questions will be shortly discussed. ${ }^{4}$

Syntactically, chapters 1-2 are clearly structured. The opening scene in Job 1:1-3 gives a characterisation of the protagonist. In short brushes Job is sketched by place and name and characterised as blameless and god-fearing. That is to say, this verse does not describe his actions but qualifies his location and properties. ${ }^{5}$ Also, the verbal clause in v. 2 does not express his action of begetting

4 For a recent survey and an extensive description of narrative and narratological approaches, see D. N. Fewell, ed., The Oxford Handbook of Biblical Narrative (New York: Oxford University Press, 2016).

5 Contra NJPS that translates v. 1c as actions, "he feared God and shunned evil." Active participles represent an action as a state and do not express a temporal value. Instead, it explains it as an atemporal relation: "He is god-fearing and shunning evil." (For a further explanation of participles, see E. J. van Wolde, Reframing Biblical Studies: When Language and Text Meet Culture, Cognition and Context (Winona Lake: Eisenbrauns, 2009), 148-51. 
children as a temporal process, but rather the collocation ויולדו לו describes the result of this process and the Niphal verb expresses the resultative state: "to him were born seven sons and three daughters." Job's wealth is subsequently depicted in two lines, both marked by ויהי v. 3a and 3b: he has large cattle and large household, and is wealthier than everyone in the East. This general qualification is clearly the work of the narrator who presents this picture from the outside as the introduction of what is to follow.

This narrator describes in v. 4 the actions of Job's sons as repetitive actions, correctly translated in the NJPS as "it was the custom of his sons to hold feasts," only to introduce Job's impeccable reaction in v. 5, "every time when a round of feast was over, Job brings sacrifices on behalf of his sons in case they had sinned." And the narrator finishes his description, adding his own comments "this is what Job always used to do." Therefore, vv. 4-5 still belong to the introductory section of the prologue, for in these verses the narrator characterises and qualifies Job and his way of life. This changes in v. 6. After the short qualification of the protagonist in vv. 1-5 follows a series of episodes marked by ויהי (1:6-12, 1:13-22, 2:1-6, 2:7-10), only the last section (2:11-13), in which the arrival of Job's friends is presented, is not marked by the section opener. In each episode, the syntactic structure is quite simple: after the opening ויהי היום "one day it happened that ..." (in v. 1:6, 1:13, and 2:1) follows a series of actions expressed in wayyiqtol forms that predominantly describe events of coming and going.

The first section (vv. 6-12) opens with the sons of God ויבאו "came" and the satan ויצא "came also" and concludes with went away" (v. 12b). Set in between these movements is the exchange between YHWH and the satan in vv. 7-12a, all marked by the verbs ויעמן "he said" and "he answered."

The second section (vv. 13-22) opens with the arrival of the messenger ( בא "came") in v. 14 against the background of the feasting of Job's sons ("it happened on a day that while the sons of Job were dining and feasting, a messenger came to Job and said"). This pattern of the arrival of a messenger is three times repeated in v. 16, 17, and 18 (three times וזה בא, "this one came"). Again, positioned in between these spatial movements are the directly reported speeches of the messengers, all marked by the verbs ויאמר "he said." However, at the end of this section, in v. 20, the narrator sketches Job's reaction in short verbal clauses, with verbs of action expressed by wayyiqtol forms: "Job arose, tore his robe, cut off his hair, threw himself on the ground, and worshipped," and by directly reporting his words (ויאמר "he said"). Even more striking is the fact that the narrator explicitly adds his own view on the case: "for all that, Job did not sin nor did he cast reproach on God." In this way, the narrator emphasizes Job's reaction on the events and his own positive evaluation of Job's behaviour. 
The third section (vv. 2:1-10) repeats the pattern of 1:13-22. A new starting point is marked by "it happened one day" (2:1), followed by the arrival of the sons of God and the satan and by the satan's departure in v. 7, which forms the spatial framework of the dialogue between YHWH and the satan. The narration of the blows inflicted by the satan on Job is followed by a directly reported dialogue between Job's wife (marked by ותאמר) and his answer (ויאמר). The narrator's concluding comment in 2:10b is worth noticing. Again, the narrator expresses his evaluation: "for all that Job did not sin with his lips." Though still positive, the explicit acclaim of 1:22 seems to be toned down.

The last section in 2:11-13 introduces Job's three friends and functions as bridge between the prologue and the chapters containing the dialogues between Job and his friends.

This syntactic and narratological analysis shows that three times the narrator actively intervenes in the story, in v. 1:5, 1:22 and 2:10. The narrator's comments share three features: (1) "all days," "in all that," and "in all that" stress the duration and continuous behaviour of Job; (2) the notion of sin חטא and its negation-in 1:5 it is implicit in "thus," referring to the previously (supposed) sins of his sons, and in 1:22 and 2:10 the negation of sinful behaviour is from Job's side; and (3) the notion of curse or blasphemy, again denied in relation to Job's sons and himself, in which the used terms תפלה, בשפתיו express disrespectful speech acts directed towards the deity. These three features "always," "not sin," and "not curse" summarize Job's impeccable behaviour from the narrator's point of view. Job's behaviour is blameless, as was already expressed in the introduction in 1:1 and in YHWH's directly reported speech in vv. 1:8 and 2:3. By presenting YHWH's views in terms similar to his own terms, the narrator makes his evaluation unescapable for the reader. The implication is that the reader has to conclude that Job himself is not to blame for what is happening to him.

In short, both the triple qualification of Job as blameless and God-fearing by narrator and YHWH as well as the narrator's own triple positive comments are the rhetorical strategy by which the reader is guided to share the narrator's perspective and positive evaluation of Job.

\section{THE SYNTACTIC STRUCTURE OF 2:7-8}

After the second dialogue in 2:1-6 the satan leaves from the presence of YHWH. The next clauses describe the subsequent events as follows:

וצא השטן מאת פני יהוה 
The narrator presents a series of actions in three verbal clauses (vv. 7a, $7 \mathrm{~b}, 8 \mathrm{a})$ marked by a wayyiqtol verb form in the 3rd person masculine singular and in one compound nominal sentence (v.8b), with a fronted personal pronoun and a participle in 3rd person masculine singular. In the first clause, v. 7a, the satan is said to leave from the presence of YHWH. In v. 7b, no new subject is mentioned, and the action performed is still that of the satan: he inflicts sores on Job. The next clause, v. 8b, appears to continue the series of actions, since no new subject is introduced. This is further confirmed by the fact that the preposition לו refers to the recipient Job, who was also the recipient of the blows reported in v. 8a. In translation: the satan left YHWH, he inflicted sores on Job, and he brought him something. Remarkably, most translations consider Job to be the agent-subject of the action in v. 8a, although no indication whatsoever is provided by the text. The King James Version is the only exception, because it takes correctly the satan as agent-subject of the verb לקח. From a syntactic point of view, the difference between, on the one hand, the three wayyiqtol-clauses in vv. $7 \mathrm{a}, 7 \mathrm{~b}$, and $8 \mathrm{a}$ with the satan as agent subject, and, on the other hand, the compound nominal sentence in v. 8b with Job as experiencer-subject, is clear. By placing the personal pronoun הוא in front position, the new subject is clearly marked and the predicate in the participial clause describes the state of that subject: "and/while he - he was sitting among the ashes."

In sum, the satan is the agent-subject of the actions described in vv. 7a, $7 \mathrm{~b}$, and $8 \mathrm{a}$, and this Hebrew text should be translated as "the satan went away from YHWH, inflicted Job with sores ... and took him a pot/sherd." In vv. 7a-8a the satan is the agent-subject, that is, the satan is the syntactic subject with the semantic role of agent, whereas in v. $7 \mathrm{~b}$ Job is the grammatical object with the semantic role of patient (marked by the nota accusativi את־ איוב), and in v. 8a, Job is the indirect object and takes the semantic role of recipient (marked by the preposition לו). Only in v. $8 \mathrm{~b}$ is Job the experiencer-subject (the syntactic subject with the semantic role of experiencer). This change in subject position is clearly marked by the personal pronoun הוא in fronted position in v. 8b, while the participle "sitting" expresses simultaneity. So, while Job was sitting among the ashes, the satan brought him a חרש.

\section{E A SEMANTIC ANALYSIS OF JOB 2:8: THE PROBLEM OF THE POTSHERD}

Verse 2:8a is an intriguing clause: "the satan took x to him in order to y in it." The verb לקח is quite simple and designates "take." The noun חרש is more 
difficult. It occurs 17 times in the Hebrew Bible: 7 times in collocation with כלי "vessel of earthenware," and in these cases it denotes an earthen vessel in which one puts food, water, blood, wine, or a document for safe keeping etc. Without כלי it is used 10 times: it is made of soil (Isa 45:9), covered with silverwork (Prov 26:23), crashed (Jer 19:1), drained to the bottom (Ezek 23:34). Once it is used in a simile, when the children of Zion are compared to precious pots (Lam 4:2). Finally, in the description of Leviathan in Job 41:22 the collocation חדודי חרש occurs, and its meaning is unclear. Although in all these usages of חרש the term clearly denotes a container of earthenware, the same term is commonly interpreted in Job 2:8 to designate a "potsherd." The concept of "potsherd" includes the notion of a piece of broken earthenware. A pot or vessel is a container, whereas a potsherd is not a container anymore. In biblical scholarship, ${ }^{6}$ the explanation of חרש as a potsherd is based on (1) references to Isa 30:13-14 and Job 41:22, in which חרש is explained as denoting a "potsherd,"7 (2) the verb התגרד is understood to designate "to scratch" and since one cannot scratch with a pot it should be a potsherd, and (3) the context of Job 2: why would the satan do something favourable for Job, why would he help him by giving him a pot? These elements will be further discussed. ${ }^{8}$

6 Cf. R. Gordis, The Book of Job: Commentary, New Translation, and Special Studies (New York: Jewish Theological Seminary of America, 1978); N. C. Habel, The Book of Job: A Commentary (Old Testament Library, London: SCM Press, 1995); D. J. A. Clines, Job 1-20 (Word Biblical Commentary 17; Dallas: Word Press, 1989); C. L. Seow, Job 1-21: Interpretation and Commentary (Grand Rapids: Eerdmans, 2013).

7 See E. Dhorme, A Commentary on the Book of Job (trans. H. Knight London: Thomas Nelson, 1967), 18.

8 The Septuagint translates חרש with ő Ancient Greek: 1. shell or housing, of marine or terrestrial animals, 2. vase, of terracotta, and, by extension, fragment of terracotta, potsherd (F. Montanari, The Brill Dictionary of Ancient Greek, Leiden: Brill 2015, 1496). In other words, the Greek word's first meaning is a container (shell or vase), which by metonymic extension came to be used for a fragment of a container. In reference to our discussion whether חרש designates "pot" or potsherd," the Greek lexeme is, therefore, not be of much help. It is even of less help, because the Septuagint offers an unreliable translation of the book of Job: it is a sixth shorter than MT and very free; indeed, it is the least literal Greek translation of any book in the Septuagint (for an extensive discussion see C.L. Seow, Job 1-21. Interpretation and Commentary. Grand Rapids, Michigan/Cambridge, UK: Eerdmans 2013, 6-9). The Septuagint can, therefore, not be used for the semantic study of the Hebrew word חרש. Hieronymus' Vulgate translation of the Book of Job does not reflect a direct translation of the Hebrew but rather a rendition of one of the Greek translations, usually Symmachus (see Seow, 12-13). Also the Rabbinic Targum of Job 
In Isa 30:13-14 $14^{9}$ the word חרש is used in metaphorical context in which sin is compared to a break in the wall that will cause it to collapse and the collapsing wall is compared to the breaking of a potter's jar, "so that there will not be found in its pieces a חרש to take ${ }^{10}$ fire from the hearth ${ }^{11}$ or scoop ${ }^{12}$ water from a cistern. ${ }^{13}$ " Can one scoop water from a cistern with a potsherd? Or take fire from a hearth with a broken piece of pottery? It seems most unlikely. The reason why commentators choose to translate it with a potsherd lies in the fact that they connect it with the described actions of smashing or crashing in v.14a, assuming that this would lead to earthenware broken into pieces. However, v. 14b does not connect the חרש to the previously described actions in v. 14a but to the infinitive: one cannot find a חרש as an instrument to take water with from a cistern, and this could never have been executed with a sherd. So, the standard meaning of pot or vessel for חרש stands up to reason in Isa 30:14, too.

In Job 40:25-41:26 YHWH paints an impressive picture of Leviathan, of חדודי חדוד is a hapax legomenon in the Hebrew Bible. Also v. 22b, "he (= Leviathan) spreads out חרוץ over the mud," remains unclear, because the noun חרוץ is, again, a difficult term to understand. According to the dictionaries it stands for "gold," "threshing sledge," "canal, ditch," while the cognate noun חריץ denotes "pickaxe" or "channel." David Clines discusses all elements of v.

does not offer information for a semantic study of Biblical Hebrew, since the earliest extant witnesses of the Rabbinic Targum of Job are fourteen manuscripts dating to the thirteenth to sixteenth centuries $\mathrm{CE}$ and these witnesses represent four different recensions (see Seow, 14-15).

9 Full translation: "This iniquity shall be on you, like a spreading break in a high wall, whose collapse comes suddenly, in an instant. And whose collapse is like the breaking of a potter's jar so ruthlessly shattered that there will not be found in its pieces a חרש to take fire from a hearth or to scoop water from a cistern."

10 The verb used in Isa 30:14 is חתתה "to take away," that occurs four times in the Hebrew Bible, three times in relation to (coals of) fire (Isa 30:14, Prov 6:27, 25:22), once, in Ps 52:7, to denote "to destroy a person" (viz. "God will destroy you") which may or may not imply in its base the meaning of fire. The noun מחתה (33 attestations, e.g., Ex. 27:3, $1 \mathrm{Kg}$ 7:50) denotes a firepan.

11 The noun used in Isa 30:14 is יקוד, "hearth" which is a hapax legomenon.

12 The verb used in Isa 30:14 is (2x) to scoop up water from cistern (Isa 30:14) and liquid from winepress (Hag 2:16).

13 The noun used is גבא, here and in Ezek 47:11, designating cistern, puddle, or swamp. 
$22 \mathrm{ab}$ extensively, with the proposals and emendations made in previous scholarship showing the many uncertainties of this verse. ${ }^{14}$ It seems that whether חרש in Job 41:22 designates precisely either "pot" or "potsherd" is uncertain and thus it is unhelpful for adding context to our present discussion.

In sum, the noun חרש designates in all attestations in the Hebrew Bible "pot" or "vessel," while its meaning in Job 41:22 is unclear. The reason why exegetes and translators of the book of Job opt for the exceptional meaning of potsherd in Job 2:8 is its combination with the verb התגרד, which is understood as a Hitpael of גרד, "scratch, scrape." And since one cannot scratch with a pot, it should denote a potsherd.

The meaning of the verb התגרד (Hitpael of is uncertain because it is a hapax legomenon. The Hitpael itself may express a reflexive or a middle voice, referring to an action in which the subject is the agent and the patient at the same time, or is as a subject affected by the action. Hence, Job is the subject-agent and at the same time affected or involved. The only other attestation of the Hebrew verb גרד (Hiphil of גרד in in the Temple Scroll (11Q19) 49:12, "And on the day when they bring out the deceased from it, they shall clean the house of all tarnishing through oil and wine and moisture of water. Its floor and its walls and its doors they shall scrape off and its door locks and its doorposts and its thresholds and its lintels they shall wash down with water ... ." ${ }^{15}$ In this text, the door, the wall, and the floor are the indirect objects or beneficiaries of the Hiphil verb, whereas the dirt, the impure matter that is to be removed, is absent as a direct object. Apparently, "one scrapes off" and not "one scrapes [something] off." Also in Mishnaic Hebrew, in Jewish Aramaic, and in Syriac comparable verbs denote "to scrape/scrape off."

14 D. J. A. Clines, Job 38-42 (Word Biblical Commentary 18B; Nashville: Thomas Nelson, 2011), 137-39.

15 Translation from J. Maier, The Temple Scroll: An Introduction, Translation and Commentary (JSOTS 34) (Translation by R. T. White from the German original Die Tempelrolle vom Toten Meer, Munich: Ernst Reinhardt Verlag 1978; Sheffield: Sheffield University Press, 1985), 43.

16 In Mishnaic Hebrew, גריד means "to scrape, scratch, comb, or strip,", part. pass. "stripped" (acc. M. Jastrow, A Dictionary of the Targumim, the Talmud Babli and Yerushlami, and the Midrashic Literature [London: Luzac, 1903], 265; b. Sabb. 109b "which has been stripped of its rind from the top downward"). In Jewish Aramaic (e.g., in TgJonJdg 8:16 where it occurs in the pael †גריד) and in Syriac it means "to scrape" or "to scrub (off)," or, less specifically, "to drag (something) across (something)." The Peshitta of Job 2:8 uses mtgrdw in the ithpaal wnsb lh hsp' lmtgrdw bh "and he (Job) took for himself the potsherd (in order) to scrape against/on himself." In a Christian Palestinian Aramaic (Syriac) manuscript for Job 7:5 the same verb shows up in a Pe'al 
in Job 2:8 designates the action "to scrape off" or "to scrape of (something dirty)."

The term שחין denoted "inflammations," "sores," or "ulcers," and is used 13 times in the HB to refer to pestilence as one of the plagues (Exod 9:9,10, 11 [x2] and Deut 28:27, 35), where it describes the inflammation that breaks out in boils on the bodies of the Egyptians, to leprosy (Lev 13:18, 19, 20, 23) pictured as an inflammation on the skin, and $2 \mathrm{Kgs} 20: 7$ and Isa 38:21 to the severe illness of Hezekiah, and in Job 2:7. Hence, in all these occurrences, the notion of a skin disease in combination with inflammation characterizes its meaning. To scratch such boils because they are itching is therefore unlikely, because that would spread the inflammation. ${ }^{17}$ More likely is that one squeezes the pus out of the inflamed ulcers in order to disinfect them, that is, to wash them out so that the healing process is speeded up. The Hitpael התגרד in Job 2:8 expresses that Job performs this action on himself. Subsequently, the discharge or pus can be collected in a pot. The application of the verb גרד is very similar to the only other attestation of the term in the Temple Scroll, where the verb גרד in Hiphil is used without a direct object: the stripping off does not mark the matter that is stripped off, but only the action of removal or forcing out.

In short, the Hitpael התגרד in combination with the preposition "in it" leads to the following translation of Job 2:8: "he (= the satan) took a pot to him (= Job) to scrape of pus into it (= the pot)."

\section{F WHY WOULD THE SATAN HELP JOB?}

The last remaining question is why the satan, who, because of a heavenly test, took everything away from Job and who inflicted Job with inflammable sores, would now help Job and offer him something positive? The reason why the narrator includes this event in his story is not to throw a positive light on the satan's behaviour. On the contrary, the rhetorical strategy is to express how terrible these inflammations are. When you need a pot to collect the squeezedout secretion from the inflamed ulcers, demonstrates how seriously bad Job's condition is. An entire pot filled with pus! Thus, it confirms the description of v. 7: "he inflicted a severe inflammation on Job from the sole of his foot to the crown of his head." By presenting the pot as the container of scraped-off pus, this narrator intensifies the horror, making the reader shudder in abhorrence. They flinch away and feel deeply sorry for him.

(G) form "I dissolve () the clods of earth from the pus I scrape off [break in ms.]." Septuagint and Vulgate have Job scraping of pus from his sores.

17 It is also unlikely that one scratches inflamed sores with a potsherd, because this would hurt too much. 


\section{G CONCLUSION}

In this analysis of Job 2:8, three components are extensively discussed: (1) The syntactic structure that shows that the subject of the action of "taking" is the satan and not Job; (2) The semantic analysis of the occurrences of the noun חרש, which demonstrates that this word does not designate "potsherd," but "pot"; and (3) The semantic exploration of the infinitive hitpael התגרד, which explains why the satan would bring Job a pot, namely to scrape of the pus from his inflamed sores that covered him from head to toe.

This results in the following translation of Job 2:7-8:

7 And the satan went out from the presence of YHWH and inflicted serious inflammations on Job from the sole of his foot to the top of his head

8 and he brought him a pot to scrape pus into it, while he (Job) sat among the ashes.

\section{BIBLIOGRAPHY}

Clines, D.J.A. Job 1-20. Word Biblical Commentary, 17, Dallas: Word Press, 1989.

Clines, D.J.A. Job 38-42. Word Biblical Commentary, 18B, Nashville: Thomas Nelson, 2011.

Dhorme, E. A Commentary on the Book of Job. Translation by H. Knight from the French original Le Livre de Job, Paris: Gabalda 1926. London: Thomas Nelson, 1967.

Fewell, D.N. (ed.) The Oxford Handbook of Biblical Narrative. New York: Oxford University Press, 2016.

Gravett, E.O. "Biblical Responses: Past and Present Retellings of the Enigmatic Mrs Job," Biblical Interpretation 20, 2010, 97-125. https://doi.org/10.1163/15685 1512 X618560

Gordis, R. The Book of Job: Commentary, New Translation, and Special Studies. New York: Jewish Theological Seminary of America, 1978.

Habel, N.C. The Book of Job. A Commentary. Old Testament Library, London: SCM Press, 1995.

Jastrow, M. A Dictionary of the Targumim, the Talmud Babli and Yerushlami, and the Midrashic Literature, London: Luzac, 1903.

Joüon, P. and Muraoka, T., A Grammar of Biblical Hebrew. $2^{\text {nd }}$ ed. Subsidia Biblica 14/1-2. Rome: Pontifical Biblical Institute, 2006.

Maier, J. The Temple Scroll: An Introduction, Translation and Commentary. JSOTS, 34, Translation by R.T. White from the German original Die Tempelrolle vom Toten Meer, Munich: Ernst Reinhardt Verlag 1978, Sheffield: Sheffield University Press, 1985.

F. Montanari, The Brill Dictionary of Ancient Greek, Leiden: Brill 2015.

Seow, C.L. Job 1-21: Interpretation and Commentary. Grand Rapids, Michigan / Cambridge, UK: Eerdmans, 2013.

Wolde, E.J. van, Mr and Mrs Job. London: SCM Press, 2003. 
704 van Wolde, “The Problem of the Potsherd," OTE 31/3 (2018): 692-704

Wolde, E.J. van, Reframing Biblical Studies. When Language and Text Meet Culture, Cognition and Context. Winona Lake (IND): Eisenbrauns, 2009.

Wolde, E.J. van, "Chance in the Hebrew Bible: Views in Job and Genesis 1", in K. Landsman and E. van Wolde (eds.), The Challenge of Chance. A Multidisciplinary Approach from Science and the Humanities. The Frontiers Collection, Springer: Open Access, 2016, 131-150. https://doi.org/10.1007/9783-319-26300-7_7

Ellen van Wolde, Radboud Universiteit Nijmegen, Faculteit der Filosofie, Theologie en Religiewetenschappen, Postbus 9103, 6500 HD Nijmegen, e.vanwolde@ftr.ru.nl ORCID ID: https://orcid.org/0000-0002-6383-3865. 